\title{
Chemical evidence from laboratory experiments for biokarst development in the Ordos Basin, northwestern China
}

\author{
Feng'e Zhang ${ }^{1, *}$, Sheng Zhang ${ }^{1}$, Miying Yin ${ }^{1}$, Ze $\mathrm{He}^{1}$, and Xinxin Geng ${ }^{1}$ \\ ${ }^{1}$ No.268, Zhonghua North Street, Xinhua District Shijiazhuang City, Hebei Province, China
}

\begin{abstract}
The present work is designed to simulate the dissolution of sulphate rock under various conditions of different bacterial cell numbers, temperatures and reaction times both in water-rock system and water-rock-bacteria systems by laboratory experiment. The rate of sulphate reduction were estimated using the experimental data. The results suggested that the sulphate-reducing bacteria promote the sulphate rock dissolution and increase the amount of dissolved sulphate. The dissolution of sulphate rock driven by bacterial sulphate reduction results in the formation of sulphate rock karst. The research is an insight into biokarst, which provides a new perspective for the field of petroleum geology.
\end{abstract}

\section{Introduction}

The Ordos Basin, characterized by low $\mathrm{H}_{2} \mathrm{~S}$ content gas fields, is the second largest oil/gas basin in China. The oil reservoir of this basin is the Majiagou formation of Ordovician whose lithology mainly includes dolomicrite with anhydrite (about $85 \%$ of the total thickness), fine grain dolomite and allochemical dolomite. Paleokarst exists within the supergene and buried karst zones in the basin. Previous studies suggested that the Ordovician buried karst originated by the corrosion of organic acids, carbon dioxide $\left(\mathrm{CO}_{2}\right)$ and hydrogen sulfide $\left(\mathrm{H}_{2} \mathrm{~S}\right)$, in water released under pressure [1-5]. Geological explorations have demonstrated that the karst areas developed by the water released under pressure, usually with pyritization, beneath the corroded hill [6]. Although the study of pyrite structure and its sulfur isotope noted the role of bacteria in the development of such hypogenic karst $[1,2,7]$, the effects of microbes on karst development on sulphate-deiven karst have been unanswered questions.

It has been postulated that the porosity of oil reservoir was developed through the carbonates corrosion by over-pressurized fluid [8]. However, the role of sulphate on the formation of the secondary porosity in reservoir has not been discussed. Previous research [9] has shown that the sulphate-carbonate interactions play a significant role in the development of various kinds of karst. Thus, the sulphate rock dissolution would not be neglected when discussing the development of karst in Ordos Basin. It has also been observed that the presence of microbe enhance sulphate rock dissolution and karst development $[10,11]$ and bacterial sulphate reduction (BSR) involved in the development

*Corresponding author: feng_ezhang@163.com 
of gypsum karst in the western Ukraine [10, 12], with sulphate-reducing bacteria (SRB) observed in the Zoloushka Cave, Ukraine [12] and three small gypsum karst lakes in northern Lithuania [13]. In addition, the presence of different minerals filling in the reservoir and their isotope signature indicated that the BSR had occurred in some oil basins $[1,11,14-17]$. Lu [18] successfully carried out the isolation and culture of SRB from gypsum sampled in the Majiagou formation of Ordovician in North China. The purpose of the present work is to determine the BSR in the development of karst in the Ordovician of Ordos Basin by using chemical characteristics of BSR products derived from laboratory experiment.

\section{Materials and Methods}

Sample of sulphate rock was collected from the Ordovician formation in the Ordos Basin, China. Its chemical compositions were measured. The mineral assembly and the percentage of minerals in the sulphate rock calculated based on the chemical compositions were gypsum and bassanite, $96.93 \%$ and $3.07 \%$, respectively. A mixture of sodium lactate and yeast extract was used as a carbon source for bacterial growth.

The sulfate rock was ground to a grain size of 1 to $2 \mathrm{~mm}$ in diameter, flushed with distilled water to eliminate tiny pellets, dried for 24 hours at $50^{\circ} \mathrm{C}$ in the air dry oven, sieved, weighed with 1/10,000 balance out many $25 \mathrm{~g}$, loaded into 220 -ml corrosion tubes, and disinfected for 20 minutes at $121^{\circ} \mathrm{C}$ in the autoclave. Solution with sulfate-reducing bacteria, cultured at temperatures of $35^{\circ} \mathrm{C}$ and $50{ }^{\circ} \mathrm{C}$ for 10 to 21 days, was added into each corrosion tube in a sterile room, filling $0,0.5$ and $5 \%$ of the volume of each tube. Then, the corrosion tubes were topped off with an antiseptic nutrient fluid and sealed. The tubes were put into the incubators with the temperatures of $35{ }^{\circ} \mathrm{C}$ and $50{ }^{\circ} \mathrm{C}$ for reaction. Water from the tubes was sampled every 3 or 4 days for chemical analysis [19, 20].

Samples for chemical compositions $\left(\mathrm{Ca}^{2+} 、 \mathrm{SO}_{4}{ }^{2-}\right.$ and $\left.\mathrm{H}_{2} \mathrm{~S}\right)$ analysis were sampled and measured during the experiment. $\mathrm{HCO}_{3}{ }^{-}$concentration was not measured because of the complication of analyses process resulting by the presence of $\mathrm{H}_{2} \mathrm{~S}$. SRB enumeration of bacterial liquid, oxidation-reduction potential (ORP) were also measured in the experiment.

Water samples for $\mathrm{Ca}^{2+}$ and $\mathrm{SO}_{4}{ }^{2-}$ measurement were directly sampled from the parallel corrosion tubes, which were designed for different reacted period in batch experiments. Samples for $\mathrm{H}_{2} \mathrm{~S}$ were precipitated as zinc sulfide $(\mathrm{ZnS})$ by adding the reaction solutions of the tubes into $20 \%$ zinc acetate solution. $\mathrm{Ca}^{2+}$ and $\mathrm{SO}_{4}{ }^{2-}$ concentration were measured by Gran titration method, whereas $\mathrm{H}_{2} \mathrm{~S}$ content was determined by an iodometric method. Bacterial populations were enumerated by the three-tube Most Probable Number (MPN) assay with serial dilutions in above mentioned medium. The experiment was performed in triplicate. The MPN tubes were incubated at incubator for 6 days. ORP was measured with a Hach sensION156 Meter which was calibrated before use.

\section{Results and Discussion}

\subsection{Sulphate rock dissolution in the water-rock system without bacteria}

There was no $\mathrm{H}_{2} \mathrm{~S}$ was detected in the water-rock system without bacteria, which indicated that BSR did not happen in the system. This was because the sulphate rock in the water-rock system had been sterilized and no cultured bacterial solution was added to the system. The relationships between $\mathrm{Ca}^{2+}$ and $\mathrm{SO}_{4}{ }^{2-}$ concentrations in the reaction solution in the water-rock system without bacteria in different reaction time at temperature of $35{ }^{\circ} \mathrm{C}$ and $50{ }^{\circ} \mathrm{C}$ were plotted along a line with a slope of about 1 . Both $\mathrm{Ca}^{2+}$ and $\mathrm{SO}_{4}{ }^{2-}$ 
concentration increased when temperature changed from 35 to $50{ }^{\circ} \mathrm{C}$, which gave evidence for the dissolution of gypsum and bassanite in this system. Because the solubility of gypsum was less than that of basanite and gypsum was the primary mineral in the experimental sample of sulphate rock, the dissolution characteristics of the system was dominated by gypsum. The amount of sulfate rock dissolution was estimated by using mass balance methods, which increased with temperature and reaction time.

The dissolution rate of gypsum can be described by the first-order kinetic process equation [21, 22], which were estimated by using the solubility of the gypsum at temperature $35{ }^{\circ} \mathrm{C}$ and $50{ }^{\circ} \mathrm{C}$ given by Zanbak [23]. The results showed that there was a negative linear correlation between the dissolution rate and the time (Fig.1). The correlation coefficients both at tempertaures $35{ }^{\circ} \mathrm{C}$ and $50{ }^{\circ} \mathrm{C}$ were 0.98 , which indicated that the dissolution rate of gypsum in the system increased with temperature and decreased with reaction time.

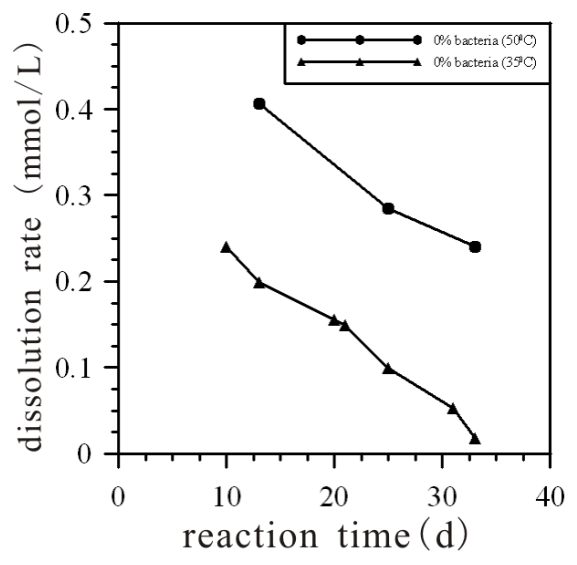

Fig. 1. Relationships between the dissolved amount of sulphate rock and reaction time in the water-rock system without bacteria.

\subsection{Geochemical processes in the water-rock-bacteria system}

The ORP values were less then $-100 \mathrm{mV}$ for the water-rock-bacteria system with filling $0.5 \%(\mathrm{v} / \mathrm{v})$ pre-grown cultures cultured at temperature $35{ }^{\circ} \mathrm{C}$ and indicated that the system was suitable for sulphate-reducing bacteria growth.

The concentration of produced $\mathrm{H}_{2} \mathrm{~S}$ increased at increased number of SRB and elevated temperature. However, there was no linear relationship between concentrations of $\mathrm{SO}_{4}{ }^{2-}$ and $\mathrm{H}_{2} \mathrm{~S}$ with different temperatures and number of SRB. Although the ratio of $\mathrm{H}_{2} \mathrm{~S} / \mathrm{SO}_{4}{ }^{2-}$ increased with the increase in the number of SRB and the reaction temperature, the ratio was less than 1 . Unlike the relationships between $\mathrm{Ca}^{2+}$ and $\mathrm{SO}_{4}{ }^{2-}$ shown in the water-rock system without bacteria, most samples showed that the $\mathrm{mCa}^{2+} / \mathrm{mSO}_{4}{ }^{2-}$ ratio were greater than 1 , and would be plotted above the line with a slope of unity in the $\mathrm{Ca}^{2+}-\mathrm{SO}_{4}{ }^{2-}$ diagram.

The bacterial sulphate reduction took place in the water-rock-bacteria system, resulting in the dissolution of gypsum. It was confirmed that the sulphate-reducing bacteria growth was inhibited by bacterial poisoning with excess $\mathrm{H}_{2} \mathrm{~S}$. The maximum concentration of $\mathrm{H}_{2} \mathrm{~S}$ in the experiment was $9.06 \mathrm{mmol} / \mathrm{l}$ and indicated that $\mathrm{H}_{2} \mathrm{~S}$ would not significant influence the sulphate reduction bacteria growth. The $\mathrm{H}_{2} \mathrm{~S}_{/} \mathrm{SO}_{4}{ }^{2-}<1$ suggested that some processes for the increase of $\mathrm{SO}_{4}{ }^{2-}$ concentration or decrease of $\mathrm{H}_{2} \mathrm{~S}$ content must take place in the system. However, the precipitation of sulfides can be neglected since the content of metals is very low in the rock sample. Thus, the increase of $\mathrm{SO}_{4}{ }^{2-}$ concentration should be responsible for the ratio of $\mathrm{H}_{2} \mathrm{~S} / \mathrm{SO}_{4}{ }^{2-}<1$. The bacterial sulphate reduction enhanced the dissolution of gypsum and maintaining the dissolution continuously in the system due to removing sulphate from solution. Bacterial sulphate reduction also produced bicarbonate $[12,19]$. Theoretically, bicarbonate combined with the $\mathrm{Ca}^{2+}$ dissolved from sulphate rock could form calcium carbonate precipitation. However, the $\mathrm{Ca}^{2+} / \mathrm{SO}_{4}{ }^{2-}$ molar concentration ratios $\left(\mathrm{Ca}^{2+} / \mathrm{SO}_{4}{ }^{2-}>1\right)$ further supported the occurrence of the above inferred the dissolution of sulphate and neglected the precipitation of carbonate. 


\subsection{Sulphate reduction rate and dissolution rate of sulphate rocks}

Sulfate reduction rates (SRR, units of $\mathrm{mmol} / \mathrm{L} \cdot \mathrm{d}$ ) for each temperature and each bacterial cell numbers were estimated based on $\mathrm{H}_{2} \mathrm{~S}$ contents produced in the water-rock-bacteria system measured during the experiments, assuming zero-order kinetics [24]. Thus, values of SRR were obtained from the slope of a straight line fitted to data of $\mathrm{H}_{2} \mathrm{~S}$ concentration vs. time using linear regression analysis. The sulphate reduction rate increased with the increase in the bacteria number or the reaction temperature, and decreased with the reaction time (Fig. 2). The amount of dissolved sulphate rock in the water-rock-bacteria system was calculated according to the remaining $\mathrm{SO}_{4}{ }^{2-}$ and produced $\mathrm{H}_{2} \mathrm{~S}$ in the system as shown in Figure 3. At the fixed experimental temperature of $35{ }^{\circ} \mathrm{C}$, the amount of dissolved sulphate rock increased with time when the bacterial cell numbers were increased from $0.5 \%$ to $5 \%$. This amount was bigger than that in water-rock system without bacteria. Comparison the rate of sulphate reduction (Fig. 2) and dissolution of sulphate rock in the water-rock-bacteria system (Fig. 4), showed that the former was lower than the latter at the early stage, and tended to be the same at the end of the experiment.

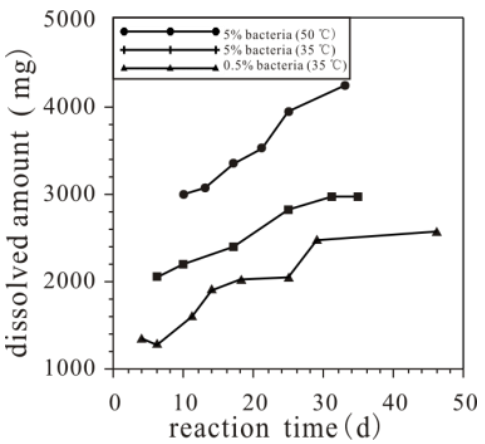

Fig. 3. Dissolved amount of sulphate rock in the water-rock system under different experimental conditions.

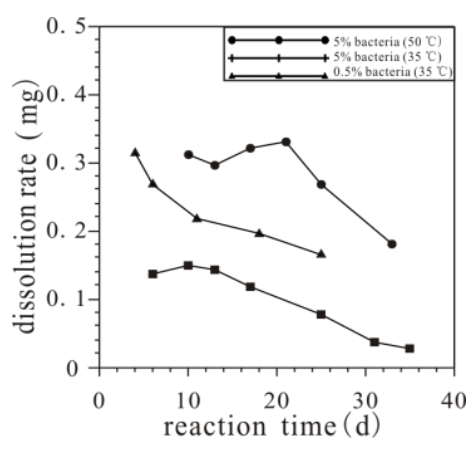

Fig. 4. Relationships between dissolution rate of sulphate and temperature, bacterial number and reaction time in the water-rock system.

\section{Conclusions}

The results show that chemical dissolution of gypsum is dominated in water-rock system without bacteria, and its dissolution rate increased with temperature and decreased with reaction time. Bacterial sulphate reduction process and the dissolution of sulphate rock driven by bacterial sulphate reduction are dominant in water-rock-bacteria system. The dissolution of sulphate rock driven by bacterial sulphate reduction resulted in the formation of sulphate karst.

This work was financially supported by the National Natural Science Foundation of China (NSFC grant No. 41072193 and No. 41472227). 


\section{References}

1. C.B. Zheng, et al., Carsologica Sinica, 16, 352-359 (1997) (in Chinese with English abstract)

2. G.S. Zhang, C.B. Zheng, Carsologica Sinica, 19, 199-205 (2000)

3. W.H. Bai, et al., Geoscience 16, 292-298 (2002) (in Chinese with English abstract)

4. S.L. Xi, et al., Acta Sedmentol Sin, 23, 354-360 (2005) (in Chinese with English abstract)

5. D.J. Huang, et al., Mar Origin Petrol Geol, 14, 10-18 (2009) (in Chinese with English abstract)

6. X.L. Zhang, et al., Soc Corros Pro, 20, 224-229 (2000) (in Chinese with English abstract)

7. F.E. Zhang, et al., Int Biodeterior Biodegrad, 76, 92-97 (2013)

8. S. He, et al., Earth Sci J China U Geosci 34, 759-768 (2009) (in Chinese with English abstract)

9. A.N. Palmer, M.V. Palmer, in: Silver Jubilee Anniversary of the Northeastern Science Foundation, Northeast Geol Environ Sci, 26, 93-106 (2004)

10. A.B. Klimchouk, Environ Geol, 31, 1-20 (1997)

11. S.J. Huang, et al., Acta Sedmentol Sin, 25, 815-824 (2007) (in Chinese with English abstract)

12. V.N. Andrejchuk, A.B. Klimchouk, Geomicrobiol J, 18, 275-295 (2001)

13. R. Paskauskas, et al., Microbiol 74, 715-721 (2005)

14. C.A. Hill, in: D.A. Budd, A.H. Saller, P.M. Harris, (Eds.) Unconformities and Porosity in Carbonate Strata, Am Assoc Petrol Geol Mem, 63, 301-306 (1995)

15. C.A. Hill, J Cave Karst Study, 62, 60-71 (2000)

16. L.D. Hose, et al., Chem Geol, 169, 399-423 (2000)

17. C.F. Cai, et al., China Offshore Oil Gas (Geol.), 12, 122-126 (1998) (in Chinese with English abstract)

18. Y.R. Lu, et al., Acta Geosci Sin, 23, 1-6 (2002) (in Chinese with English abstract)

19. F.E. Zhang, et al., Earth Sci J China U Geosci, 35, 146-154 (2010) (in Chinese with English abstract)

20. F.E. Zhang, et al., Earth Sci J China U Geosci, 37, 357-364 (2012) (in Chinese with English abstract)

21. M.A. Raines, et al., Chem. Geol, 140, 29 (1997)

22. A.B. Klimchouk, in A.B. Klimchouk, D.C. Ford, A. Palmer, \& W. Dreybrodt (Eds.) Speleogenesis: Evolution of Karst Aquifers, Huntsville, Alabama: Natl Speleol Soc, (2000)

23. C. Zanbak, R.C. Arthur, Bull Assoc Eng Geol, 23, 419-433 (1986)

24. C. Bolliger, et al., Geochim Cosmochim Acta, 65, 3289-3298 (2001) 